\title{
Physiological and Biochemical Changes in Moth Bean (Vigna aconitifolia L.) under Cadmium Stress
}

\author{
Poornima D. Vijendra, ${ }^{1,2}$ Kavitha M. Huchappa, ${ }^{1}$ Roopa Lingappa, ${ }^{1}$ Giridhara Basappa, \\ Sathisha G. Jayanna, ${ }^{3}$ and Vadlapudi Kumar ${ }^{1,2}$ \\ ${ }^{1}$ Department of Biochemistry, Kuvempu University, P.G. Centre, Shivagangothri, Davangere, Karnataka 577002, India \\ ${ }^{2}$ Department of Biochemistry, Davangere University, Shivagangothri, Davangere, Karnataka 577002, India \\ ${ }^{3}$ Department of Biochemistry, Kuvempu University, Shankaraghatta, Shivamogga District, Karnataka 577451, India \\ Correspondence should be addressed to Vadlapudi Kumar; veeke2012@gmail.com
}

Received 8 October 2015; Revised 14 November 2015; Accepted 8 February 2016

Academic Editor: Bala Rathinasabapathi

Copyright (C) 2016 Poornima D. Vijendra et al. This is an open access article distributed under the Creative Commons Attribution License, which permits unrestricted use, distribution, and reproduction in any medium, provided the original work is properly cited.

\begin{abstract}
Moth bean (Vigna aconitifolia L.), a drought resistant legume, possesses high nutritional value. Cadmium (Cd) is a nonessential and the most toxic heavy metal in plants. The present study was to test the hypothesis of whether moth bean being a drought resistant legume can withstand the cadmium stress. Ten-day-old moth bean seedlings were subjected to cadmium stress and investigated for a period of 15 days every 3-day intervals. Cadmium quantification in moth bean tissues suggests root accumulation and translocation to aerial parts in a concentration dependent manner. Results of physiological and biochemical studies revealed that cadmium has affected the growth parameters like shoot and root lengths and tissue dry weights. Significant alternations in relative water content and cell membrane stability were observed in stressed seedlings. Similarly superoxide radical, lipoxygenase activity, membrane lipid peroxidation products, protein carbonyls, and reduced glutathione and nonprotein thiols were found increased in stressed seedlings compared to controls. However, hydrogen peroxide and ascorbic acid levels were not altered significantly in both stressed and control seedlings. Cadmium translocation ability from roots to aerial parts and elevated levels of nonenzymatic antioxidants in stressed seedlings suggest the cadmium stress withstanding ability of moth bean.
\end{abstract}

\section{Introduction}

Heavy metals are of great environmental and human health concerns due to their widespread occurrence, persistence in ecosystems, and toxic properties [1]. Agricultural crops differ widely in their tolerance to toxic metals. Tolerance of plants to heavy metals is genetically determined [2], so that identification of plant genotypes differing in resistance to heavy metals is a promising approach, not only for studying mechanisms protecting plants against toxic metals, but also for the selection of those adapted to production in presence of heavy metals in contaminated soils [3].

Cadmium (Cd) is highly toxic to all living organisms and is one of the most toxic heavy metals in plants due to its high solubility in water and phytotoxicity $[4,5]$. Cadmium is not an essential nutrient in plants and at high concentration inhibits plant growth $[6,7]$; even at relatively low concentrations it alters plant metabolism [8]. Detrimental effects of cadmium are manifested in inhibition of photosynthesis and in oxidative stress leading to membrane damage [9]. The intensive application of phosphate fertilizers containing traces of $\mathrm{Cd}$ and industrial zinc mining is expanding the soilCd contamination rapidly especially in the developing countries $[10,11]$.

Moth bean (Vigna aconitifolia L.), also called mat bean or matki bean, mout bean, or dew gram or Turkish gram, belongs to Fabaceae. Moth bean is a most popular pulse crop in India. It is cultivated for its immature pods and mature seeds and is consumed by people all around the world, especially in the developing nations [12-14] as it possesses high nutritional value and is a potential source of protein and other nutrients. 
Legume crops are less tolerant to Cd toxicity than cereals and grasses and encounter strong inhibition of biomass production due to cadmium [15]. Different degrees of tolerance to cadmium stress were observed among different genotypes of the same species [16-18]. Vigna species can grow under a wide range of climates and environments [19]. Moth bean is a hot weather, drought resistant legume, particularly cultivated in hot, arid to semiarid regions. For optimum production it requires $24^{\circ} \mathrm{C}-32^{\circ} \mathrm{C}$ of temperature; however, the plant withstands daytime temperature of $45^{\circ} \mathrm{C}$ and does not tolerate water logging. Some degree of salinity and a wide $\mathrm{pH}$ range $(3,5-10)$ are tolerated $[15,20]$. Presence of cadmium in the soil decreases the growth of legumes like soybean [21, 22] and chickpea plants [23]. However, in the pertinent literature survey on moth bean and its heavy metal stress responses, few published reports $[24,25]$ are available to date revealing its cadmium stress responses.

The present study is envisaged to evaluate whether the moth bean is sensitive to cadmium like other legumes or it can withstand the cadmium stress, as this plant can withstand a wide range of environmental stresses. To test this hypothesis the present study has been taken up to evaluate the cadmium sensitivity or tolerance of moth bean plant by subjecting to different concentrations of cadmium for a short duration period of 15 days. The investigations were carried out by determining the changes in physiological growth parameters like fresh and dry mass yield, cell membrane stability, and biochemical parameters including changes in the levels of antioxidant molecules, nonprotein thiols, and antioxidant enzymes and also accumulation of cadmium in plant organs.

\section{Materials and Methods}

2.1. Plant Material and Cadmium Treatments. Seeds of Vigna aconitifolia (moth bean) cv. PS-16 were procured from local agriculture seed stores of Davangere, Karnataka State, India. The healthy and uniform sized seeds were separated, surfacesterilized with $0.5 \%$ sodium hypochlorite $(\mathrm{v} / \mathrm{v}$ in sterile distilled water) solution imbibed in sterile double distilled water for $48 \mathrm{hrs}$ in the dark, and germinated on Whatman No. 1 filter paper moistened with sterile distilled water. Twoday-old sprouts were sown in germination trays filled with cleaned and dried sand for further growth, watered daily with 1x Hoagland nutrient solution [26] for 10 days. From the 11th day considered as " 0 " day, cadmium $(\mathrm{Cd})$ in the form of cadmium chloride $\left(\mathrm{CdCl}_{2}\right)$ was supplemented in Hoagland nutrient solution at different concentrations, $10 \mu \mathrm{M}, 50 \mu \mathrm{M}$, $100 \mu \mathrm{M}, 200 \mu \mathrm{M}$, and $500 \mu \mathrm{M}$; simultaneously control group of seedlings were also maintained. Stress treatments were continued for 15 days, seedlings were removed from the individual treatment trays every 3-day intervals, and the experiments were conducted according to simple randomized block design. Experiments were conducted in two sets; for each set of experiments 20 healthy seedlings were taken at random, and roots and upper second fully expanded leaves were separated and subjected to physiological and biochemical analysis.
2.2. Plant Growth Measurements. Plant growth was assessed by measuring the shoot and root lengths and fresh (FW) and dry weights (DW) of the plants from individual treatment group. For the dry weight determination, samples were ovendried at $80^{\circ} \mathrm{C}$ for $15 \mathrm{~min}$ and then vacuum-dried at $40^{\circ} \mathrm{C}$ to constant weight and then dry weights (DW) were recorded.

2.3. Cadmium (Cd) Uptake. Amount of cadmium (Cd) in 15day stressed plant tissues was quantified by atomic absorption spectrometer analysis. Briefly, leaves and roots were separated from the plants, washed in deionized water for $2 \mathrm{~min}$, and air-dried and further drying was carried out in a microwave station at $80^{\circ} \mathrm{C}$ for 2 days. Dried plant tissue was ground into fine powder; $1 \mathrm{~g}$ of tissue powder was digested into 3 parts of di-acid mixture containing $1 \mathrm{M} \mathrm{HNO}_{3}$ and $1 \mathrm{M} \mathrm{HCl}$ (3:1 ratio) at $60^{\circ} \mathrm{C}$. Cadmium content was determined by atomic absorption spectrometer (Chemito-AA201) analysis using cadmium standard (Sigma-Aldrich, St. Louis).

2.4. Relative Water Content (RWC). Relative water content (RWC) was determined in fresh leaf discs that were weighed and immediately floated on double distilled water in petri dishes to saturate for the next $24 \mathrm{~h}$, in the dark. The adhering water was blotted and turgor weights were recorded. Subsequently dry mass was obtained after dehydrating at $70^{\circ} \mathrm{C}$ for $48 \mathrm{~h}$. Relative water content was calculated using the following formula:

$$
\mathrm{RWC}=\left(\frac{\text { Fresh mass }- \text { Dry mass }}{\text { Turgor mass }- \text { Dry mass }} \times 100\right) .
$$

2.5. Cell Membrane Stability (CMS). Cell membrane stability (\% of injury) was determined by electrical conductivity measurements [27] in control and cadmium stressed leaf discs using a conductivity meter (Systronics, India). Subsequently, the leaf tissues were killed by autoclaving at $121^{\circ} \mathrm{C}$ and $1.06 \mathrm{~kg} \mathrm{~cm}^{-2}$ pressure for $15 \mathrm{~min}$ and electrical conductivities were measured again to determine the total electrolyte concentrations.

The CMS index (\% of injury) of the leaf tissues was determined using the following equation:

$$
\begin{aligned}
& \text { Percentage of injury or CMS }(\%) \\
& \quad=100 \cdot\left\{\left\{1\left[\frac{(1 \cdot T 1 / T 2)}{(1 \cdot C 1 / C 2)}\right]\right\} \times 100\right\},
\end{aligned}
$$

where $T 1$ and $C 1$ represent the electrolyte concentrations measured after incubating at $10^{\circ} \mathrm{C}$ for $24 \mathrm{~h}$ and $\mathrm{T} 2$ and $\mathrm{C} 2$ represent the total electrolyte concentration measured after autoclaving the leaf tissues of both treatments and controls, respectively.

2.6. Estimation of Active Oxygen Species (AOS) Levels. The amount of superoxide radicals $\left(\mathrm{O}_{2}{ }^{--}\right)$was estimated by determining the amount of nitrite formed from hydroxylamine [28] in the fresh leaves and root extracts prepared separately into $65 \mathrm{mM}$ phosphate buffer ( $\mathrm{pH}$ 7.8) and supernatants were 
used for the estimation of superoxide. The reaction mixture contained $0.9 \mathrm{~mL}$ of $65 \mathrm{mM}$ phosphate buffer $(\mathrm{pH} 7.8)$ and $10 \mathrm{mM}$ hydroxylamine hydrochloride and plant tissue extract. After incubation at room temperature $17 \mathrm{mM}$ sulphanilamide and $7 \mathrm{mM} \alpha$-naphthol were added; after incubation for 5$10 \mathrm{~min}$ at room temperature, diethyl ether was added and absorbance of supernatants was recorded at $530 \mathrm{~nm}$. Amount of nitrite formed was determined with the help of a standard curve established with standard source of $\mathrm{NO}_{2}{ }^{-}$and expressed as $\mu \mathrm{M} \mathrm{g}^{-1} \mathrm{FW}$ of tissue. The amount of total hydrogen peroxide $\left(\mathrm{H}_{2} \mathrm{O}_{2}\right)$ was estimated in the fresh leaves and roots by ferrithiocyanate method [29]. Tissue homogenates were prepared into $5 \%$ trichloroacetic acid; supernatants were used immediately for the total peroxide estimation. The reaction mixture contained tissue extract, $50 \%$ trichloroacetic acid, and $10 \mathrm{mM}$ ferrous ammonium sulphate, and colour was developed with $2.5 \mathrm{M}$ potassium thiocyanate. Absorbance of reaction mixture was measured at $480 \mathrm{~nm}$ and amount of total $\mathrm{H}_{2} \mathrm{O}_{2}$ was calculated using the extinction coefficient $0.28 \mu \mathrm{mol}^{-1} \mathrm{~cm}^{-1}$.

2.7. Assay of Lipoxygenase (LOX) Activity (EC 1.13.11.12). Lipoxygenase (EC 1.13.11.12) assay was carried out in the fresh leaf and root extracts $(500 \mathrm{mg}$ ) as described by [30]. Tissue homogenates were prepared separately into $3 \mathrm{~mL}$ of $0.2 \mathrm{M}$ borate buffer ( $\mathrm{pH} \mathrm{8.0)}$ and supernatants used for the lipoxygenase assay. The assay mixture contained $0.2 \mathrm{M}$ boric acid buffer ( $\mathrm{pH} 10.0)$ and plant extract and linoleic acid as a substrate in a final volume of $3 \mathrm{~mL}$. The reaction was carried out at $30^{\circ} \mathrm{C}$ for $4 \mathrm{~min}$ and absorption of reaction mixture was measured at $234 \mathrm{~nm}$. Molar absorption coefficient of $25000 \mathrm{M}^{-1} \mathrm{~cm}^{-1}$ was used for determining the concentration of the hydroperoxides produced and lipoxygenase activity was expressed as absorbance increase $\left(\mathrm{DA}_{234}\right) \mathrm{mg}^{-1}$ of protein $\min ^{-1}$.

\subsection{Membrane Lipid Peroxidation and Protein Oxidation} Products. Membrane lipid peroxidation in leaves and roots was determined as malondialdehyde (MDA) equivalent products that react with thiobarbituric acid [31]. Absorbance of reaction mixture was measured at $532 \mathrm{~nm}$ spectrophotometrically and concentration of MDA was calculated using extinction coefficient of $155 \mathrm{mM}^{-1} \mathrm{~cm}^{-1}$ and expressed as $\mu \mathrm{M}^{-1} \mathrm{~g}$ fresh weight of tissue. Protein oxidation was measured in tissue extracts as the total carbonyl group content by reaction with 2,4-dinitrophenylhydrazine (DNPH) [32]. Tissue extracts were prepared into $5 \mathrm{~mL}$ of $50 \mathrm{mM}$ potassium phosphate buffer ( $\mathrm{pH} 7.4$ ) containing $120 \mathrm{mM} \mathrm{KCl}$ and $0.1 \mathrm{~g}$ PVP; aliquots of supernatants containing at least $0.5 \mathrm{mg}$ protein were incubated with $0.03 \%$ Triton X-100 and $1 \%$ streptomycin sulphate for $15 \mathrm{~min}$ to remove the nucleic acids. After centrifugation, equal volumes of supernatant and $10 \mathrm{mM}$ DNPH in $2 \mathrm{M} \mathrm{HCl}$ were mixed with each other, after incubation for $1 \mathrm{~h}$, proteins were precipitated with $20 \%$ TCA (w/v), precipitate was washed three times with ethanol : ethylacetate $(1: 1)$ and dissolved into $6 \mathrm{M}$ guanidine hydrochloride in $20 \mathrm{mM}$ potassium phosphate buffer, $\mathrm{pH}$ was adjusted to 2.3 with trifluoroacetic acid, and absorption was measured at $380 \mathrm{~nm}$. Carbonyl group content was calculated using a molar absorption coefficient of $22,000 \mathrm{M}^{-1} \mathrm{~cm}^{-1}$ and expressed as $\mu \mathrm{Mg}^{-1} \mathrm{FW}$.

2.9. Estimation of Nonenzymic Antioxidants. Total ascorbate was determined according to the modified procedure of [33] in fresh leaf and root tissue homogenates prepared into $5 \%$ metaphosphoric acid and dithiothreitol (for reducing dehydroascorbate to ASC) using $5 \%(\mathrm{w} / \mathrm{v}) \mathrm{N}$-ethylmaleimide and $4 \%(\mathrm{w} / \mathrm{v}) 2,2^{\prime}$-bipyridyl. Absorbance of the reaction was measured spectrophotometrically at $525 \mathrm{~nm}$ and using standard ascorbate calibration, tissue total ascorbate was determined and expressed as $\mathrm{mg}^{-1} \mathrm{~g}$ FW. Reduced glutathione content was determined using 5,5' -dithiobis-2-nitro benzoic acid (DTNB) reagent in fresh leaf and root extracts prepared separately into 5\% sulfosalicylic acid [34]. Absorbance of the reaction was measured spectrophotometrically at $412 \mathrm{~nm}$ and the amount of glutathione was determined using a standard calibration curve constructed with reduced glutathione (GSH). Similarly, nonprotein thiols (NPSH) were determined using DTNB reagent [35] in fresh leaf and root tissue homogenates prepared separately into $1 \mathrm{M} \mathrm{HCl}$ containing $1 \mathrm{mM}$ EDTA. Absorbance of reaction mixture was measured at $412 \mathrm{~nm}$ and the amount of nonprotein thiols was quantified using a reduced glutathione (GSH) calibration curve. Free cysteine content was measured using acetic acid-ninhydrin reagent in the fresh leaf and root tissue extracts prepared into 5\% perchloric acid [36]. Absorbance was read at $560 \mathrm{~nm}$ and the amount of cysteine was quantified using a calibration curve prepared with cysteine standard.

2.10. Statistical Analysis of the Data. Data from 3 trials of each experiment with at least 10 plants (tissue samples from same group) for each trial were statistically analyzed (oneway ANOVA) using GraphPad Prism software (version 3.0). Unless otherwise stated elsewhere, average values (mean) and standard errors (SE) were determined, means were compared with Dunnett's test (at 5\% level of significance), and data were represented as mean $\pm \mathrm{SE}$.

\section{Results}

3.1. Seed Germination and Seedling Growth. Seed germination was achieved within 2-3 days and the germination percentage was determined to be between 97 and $99 \%$. Seedlings attained nearly $6.5-8.2 \mathrm{cms}$ of height in 10 days on 1x Hoagland's nutrient solution.

3.2. Plant Growth Measurements. Shoot lengths and root lengths of the Cd stressed seedlings were found to be slightly affected but no significant changes were observed with the increase in stress intensity (concentration of $\mathrm{Cd}$ and duration of exposure) and duration compared to respective control group of plants (Figure 1). Similarly, a slight reduction in the dry weights of tissue mass in cadmium stressed plants was observed at all the concentrations of cadmium and duration (Figure 2). 


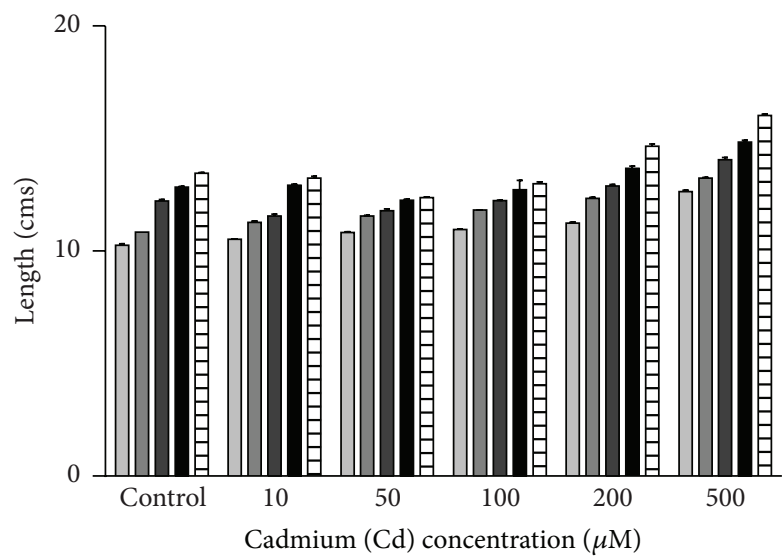

$\begin{array}{ll}\square \text { Day } 3 & \square \text { Day } 12 \\ \text { Day } 6 & \square \text { Day } 15 \\ \text { Day } 9 & \end{array}$

(a)

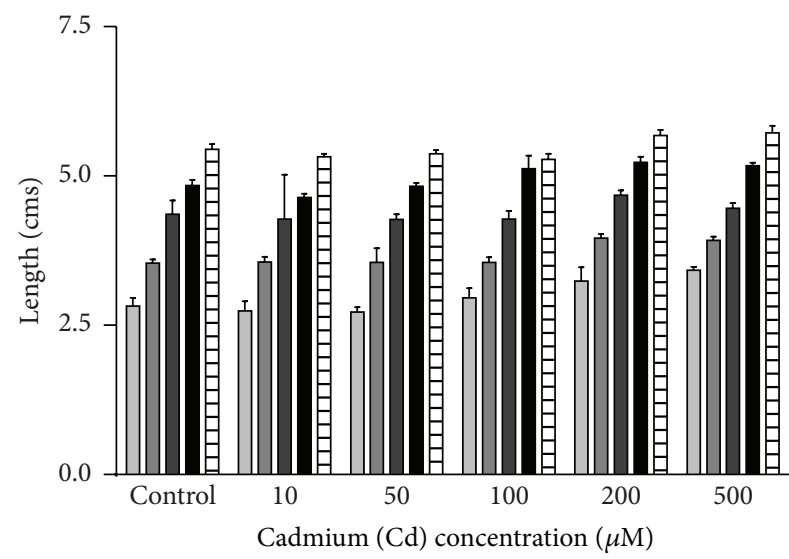

\begin{tabular}{ll}
$\square$ Day 3 & $\square$ Day 12 \\
\hline Day 6 & Day 15 \\
Day 9 &
\end{tabular}

(b)

Figure 1: Changes in (a) shoot length and (b) root length. Data shown in each bar are mean \pm SE of 3 trials of each experiment with at least 10 plants, analyzed by Dunnett's test (at $5 \%$ level of significance).
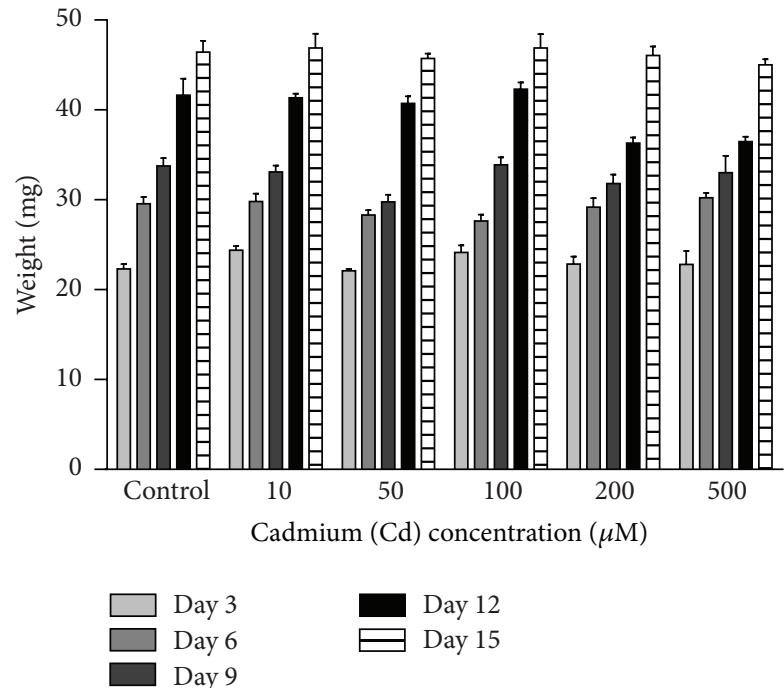

(a)
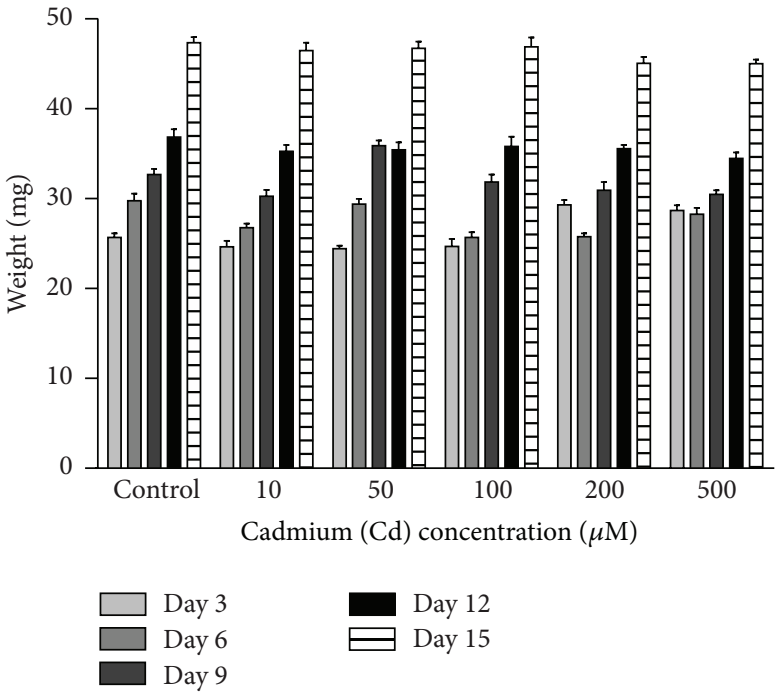

(b)
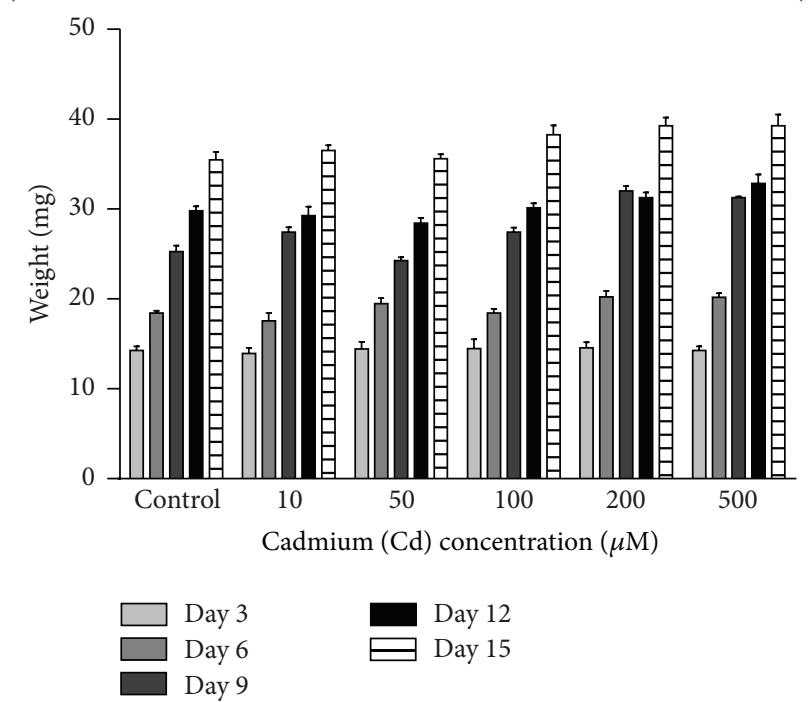

(c)

Figure 2: Changes in tissue dry weights (a) leaf, (b) shoot, and (c) root. Data shown in each bar are mean \pm SE of 3 trials of each experiment with at least 10 plants, analyzed by Dunnett's test (at $5 \%$ level of significance). 


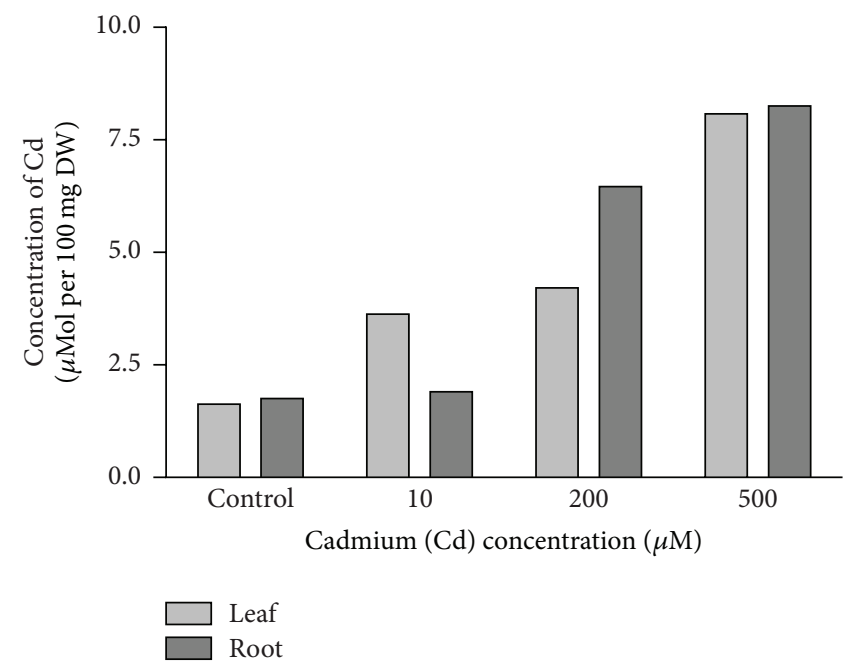

FIGURE 3: Cadmium content in tissues. Data shown in each bar are mean values from 3 trials of experiment with at least 10 plants/tissue from same group.

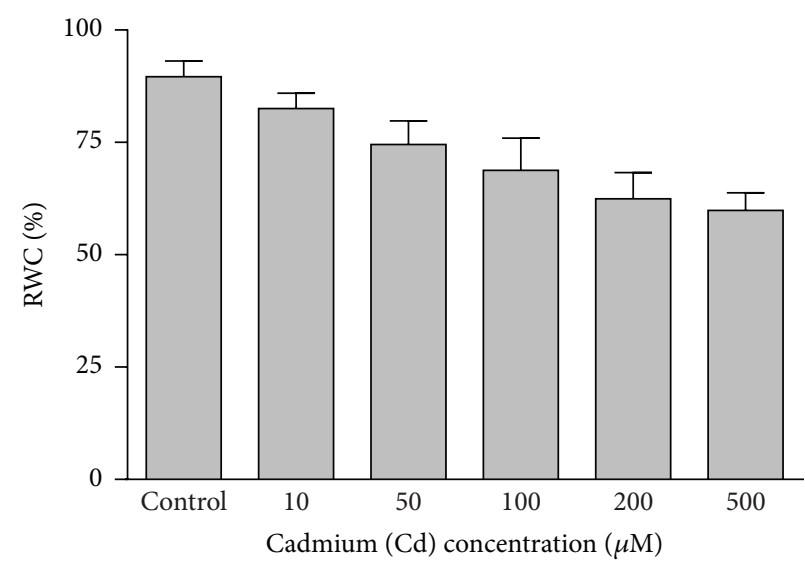

(a)

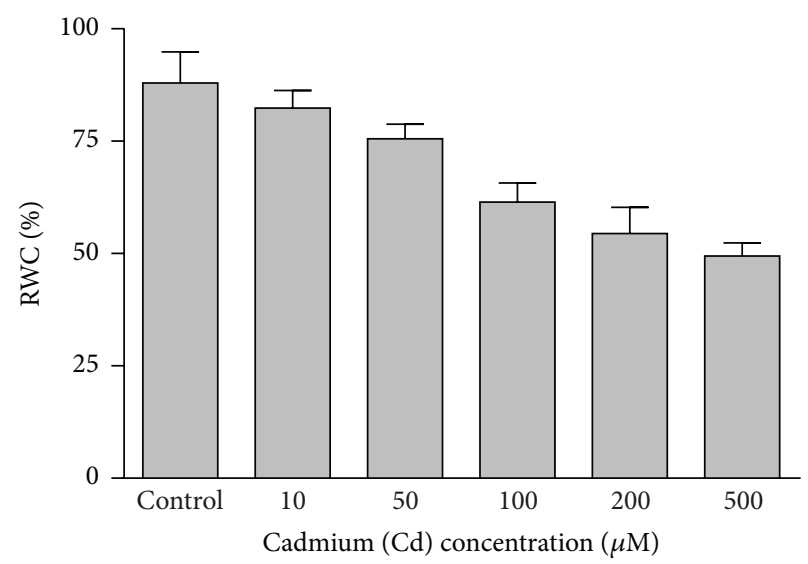

(b)

FIGURE 4: Changes in tissue relative water content (RWC \%). (a) Leaf and (b) root. Data shown in each bar are mean \pm SE of 3 trials of each experiment with at least 10 plants, analyzed by Dunnett's test (at $5 \%$ level of significance).

3.3. Cadmium Accumulation in Tissues. Cadmium content was found to be significantly increased in both leaves and roots of stressed plants compared to respective controls. Tissue accumulation was in a concentration dependent manner supplemented in the medium. Higher amounts of cadmium were determined in leaves than in roots at $10 \mu \mathrm{M}$ concentration supplemented in the medium, higher amounts in roots than in leaves at $200 \mu \mathrm{M}$ concentration supplemented in the medium, and similar amounts in both leaves and roots at $500 \mu \mathrm{M}$ concentration supplemented in the medium (Figure 3).

3.4. Relative Water Content (RWC). Relative water content (RWC) was determined in fresh leaves and roots. Significant differences in relative water content were observed between the controls and cadmium stressed plants after 15 days of cadmium exposure. In the cadmium stressed plants nearly $67 \%$ decrease in RWC was observed in leaves, while in roots the decrease in RWC was nearly 56\% (Figure 4) compared to control group of plants.

3.5. Cell Membrane Stability. Cell membrane stability or membrane injury (\%) was assessed by an indirect measurement of electrolyte leakage of the leaf discs. Significant decrease in cell membrane stability was observed in stressed plant leaves compared to control group leaves. There was an inverse relationship observed between the intensity of cadmium stress and cell membrane stability. Greater than or equal to $100 \%$ injury was observed only at $500 \mu \mathrm{M}$ cadmium stress, while at other concentrations of cadmium, the $\%$ of injury was observed to be less than 100\% (Figure 5).

3.6. Changes in Active Oxygen Species (AOS) Levels. Cadmium stress induced an increase in superoxide radical $\left(\mathrm{O}_{2}{ }^{--}\right)$ production in both leaf and root tissues, compared to controls with higher levels noticed in the stressed tissues. The levels 


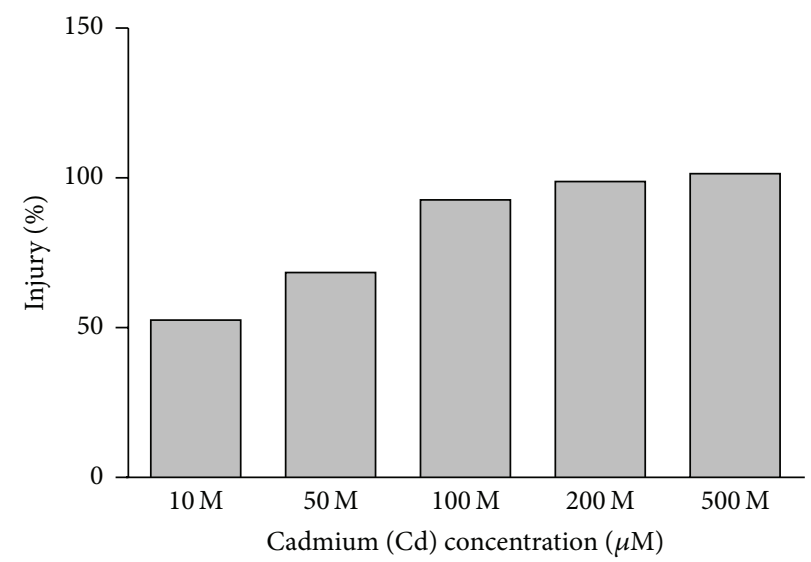

FIGURE 5: Changes in leaf cell membrane stability (injury \%). Data shown in each bar are mean values from 3 trials of experiment with at least 10 plants/tissue from same group.
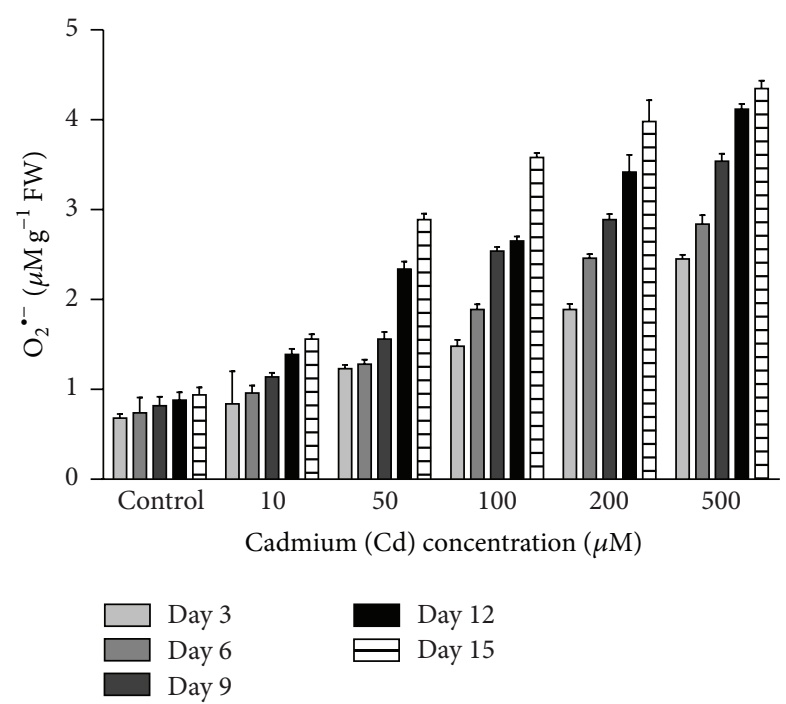

(a)
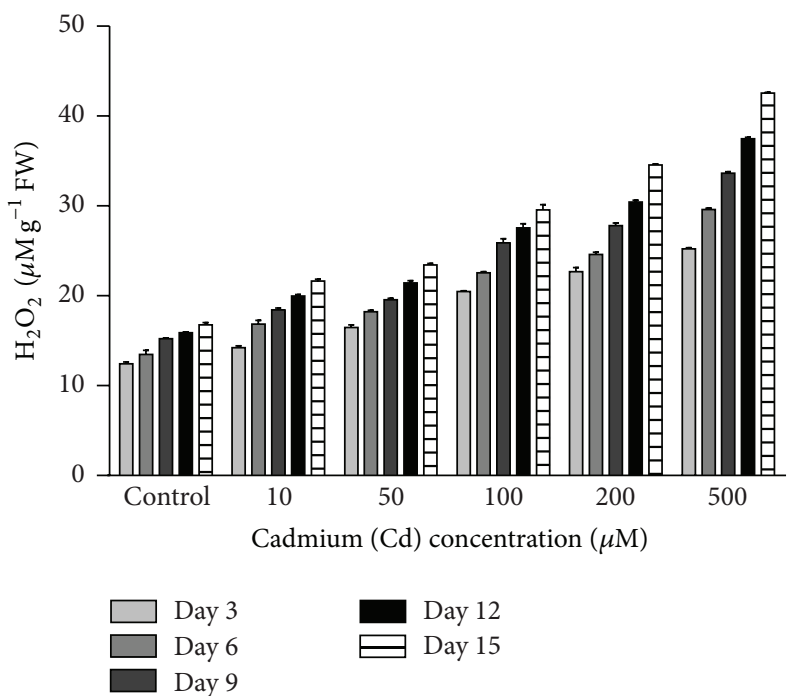

(c)
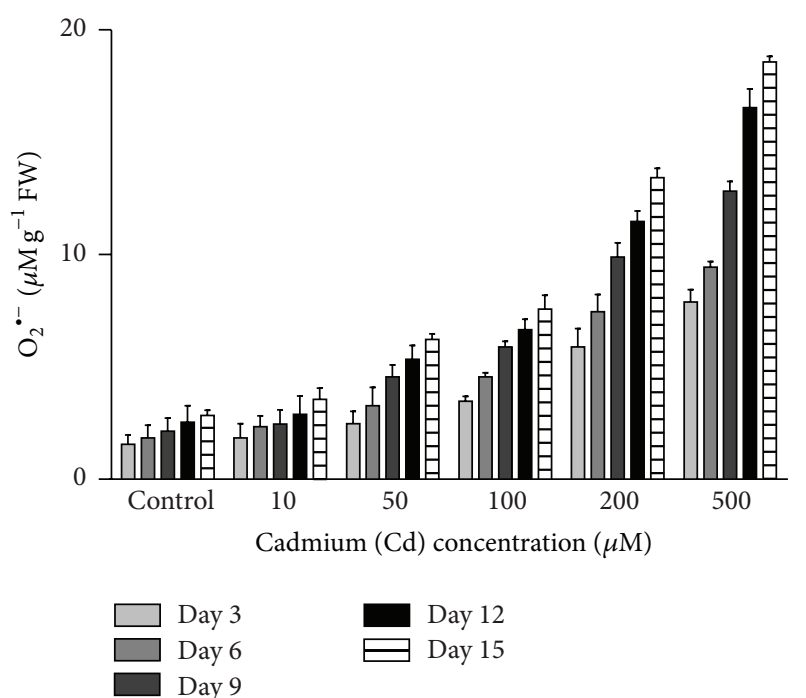

(b)
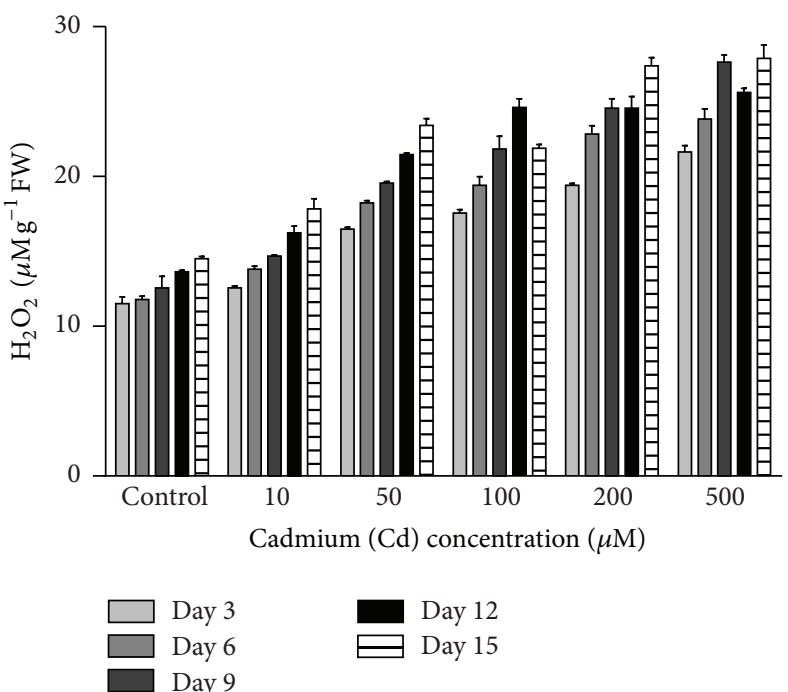

(d)

FIGURE 6: Changes in active oxygen species (AOS) in tissues. (a) Leaf superoxide, (b) root superoxide, (c) leaf hydrogen peroxide, and (d) root hydrogen peroxide. Data shown in each bar are mean \pm SE of 3 trials of each experiment with at least 10 plants, analyzed by Dunnett's test (at $5 \%$ level of significance). 


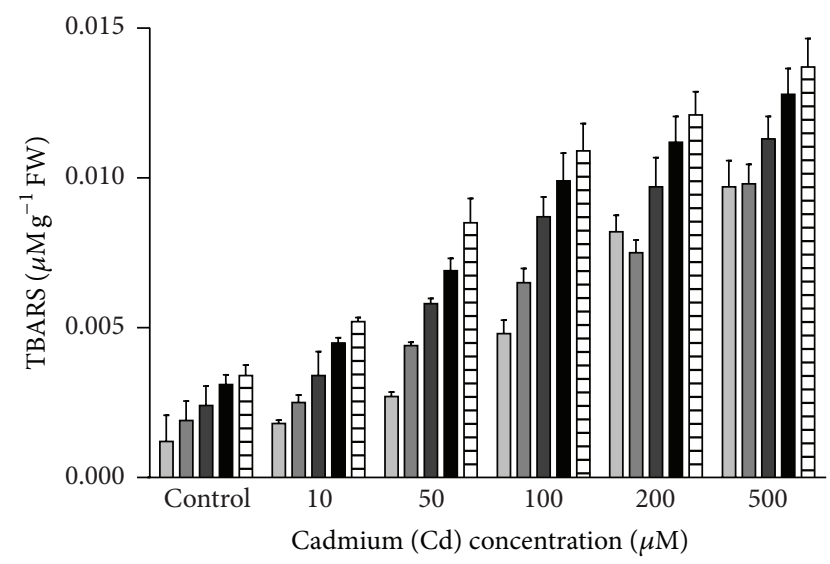

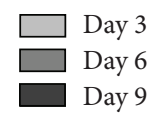

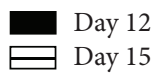

(a)
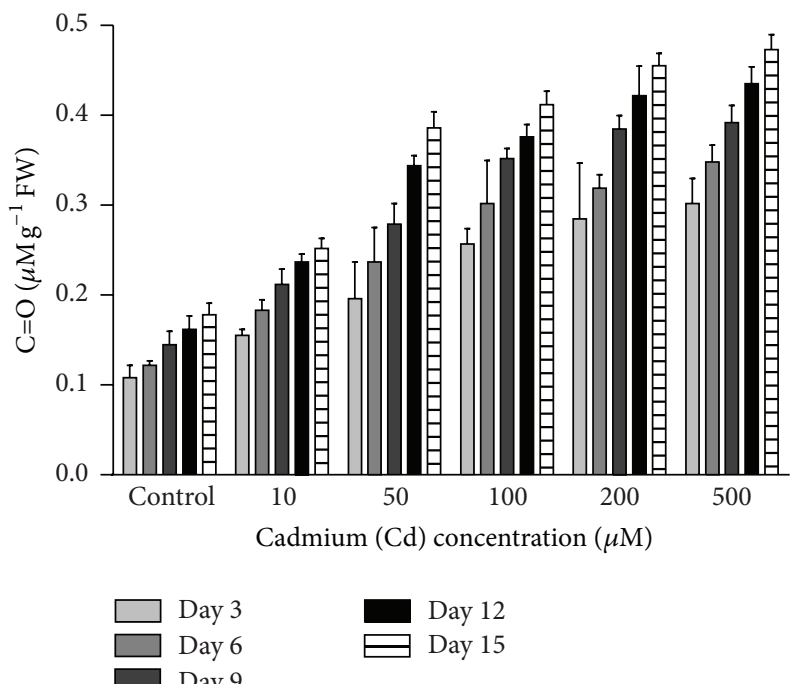

(c)
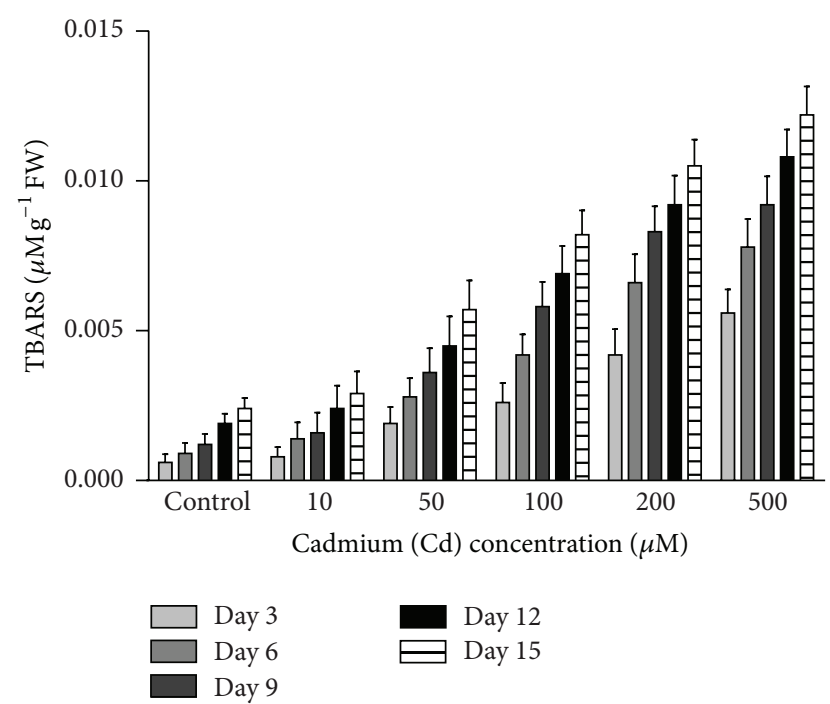

(b)
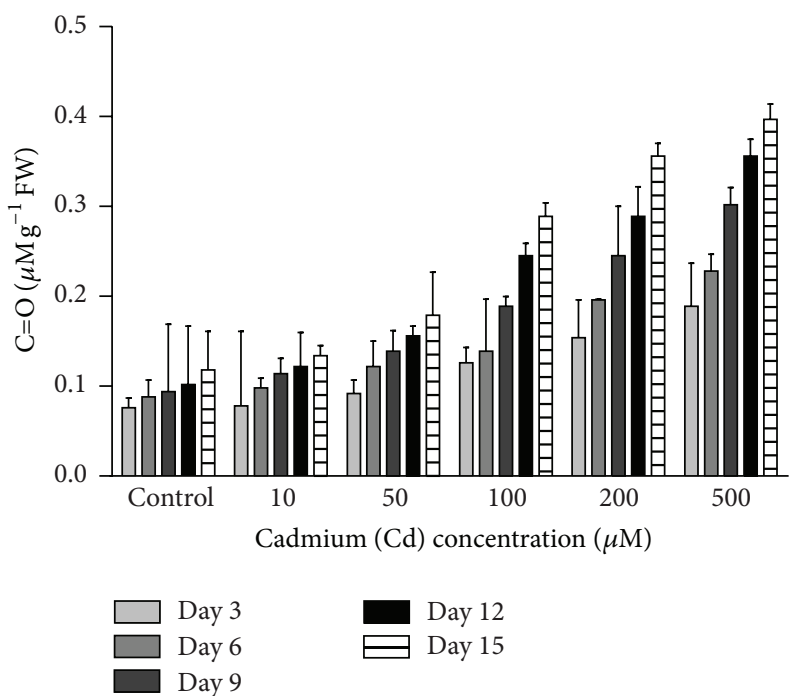

Day 15

(d)

FIGURE 7: Changes in membrane lipid peroxidation products (TBARS) and protein carbonyl $(\mathrm{C}=\mathrm{O})$ contents in tissues. (a) Leaf TBARS, (b) root TBARS, (c) leaf carbonyls, and (d) root carbonyls. Data shown in each bar are mean \pm SE of 3 trials of each experiment with at least 10 plants, analyzed by Dunnett's test (at $5 \%$ level of significance).

of superoxide radical were found to be up to 4 -fold higher in roots than in leaves. Cadmium at $500 \mu \mathrm{M}$ concentration induced about 4.0-fold increase in $\mathrm{O}_{2}{ }^{\circ-}$ production in leaves and about 6.2-fold increase in roots at the same concentration (Figures 6(a) and 6(b)). However, a consistent increase in hydrogen peroxide production was observed in both leaves and roots of stressed plants compared to controls, with higher amounts determined in leaves than in roots (Figures 6(c) and $6(d))$.

3.7. Changes in Membrane Lipid and Protein Oxidation Products. Cadmium stress caused a significant increase in the amount of lipid peroxidation in leaves and roots at all the concentrations, as measured in terms of thiobarbituric acid reactive oxygen species (TBARS) with highest amount of TBARS (MDA equivalent product); concentration was recorded in $500 \mu \mathrm{M}$ cadmium exposed plant tissues. Compared to controls about 3 -fold increase was observed in leaves and roots by day 15 (Figures 7(a) and 7(b)). Similarly, cadmium stress significantly increased carbonyl groups content in leaves and roots compared to control group of plants, with higher values recorded in leaves than in roots (Figures 7(c) and $7(d))$.

3.8. Changes in Lipoxygenase (LOX) Activity (EC 1.13.11.12). Lipoxygenase activity was found to be increased in both leaves and roots of stressed plants compared to respective controls. The increase was recorded to be consistent with the intensity of cadmium stress and duration, with higher levels in leaves than in roots (Figure 8). 

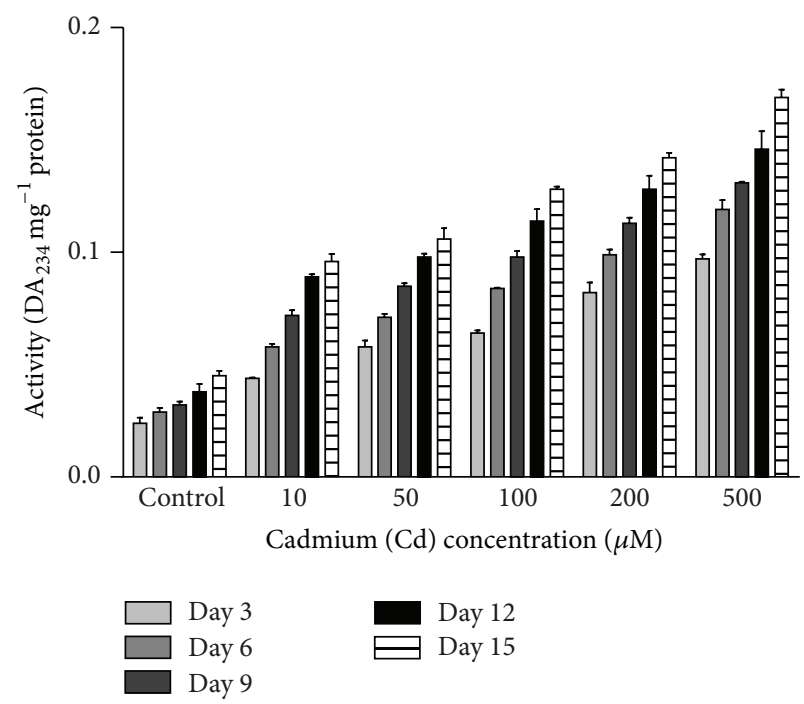

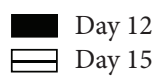

(a)
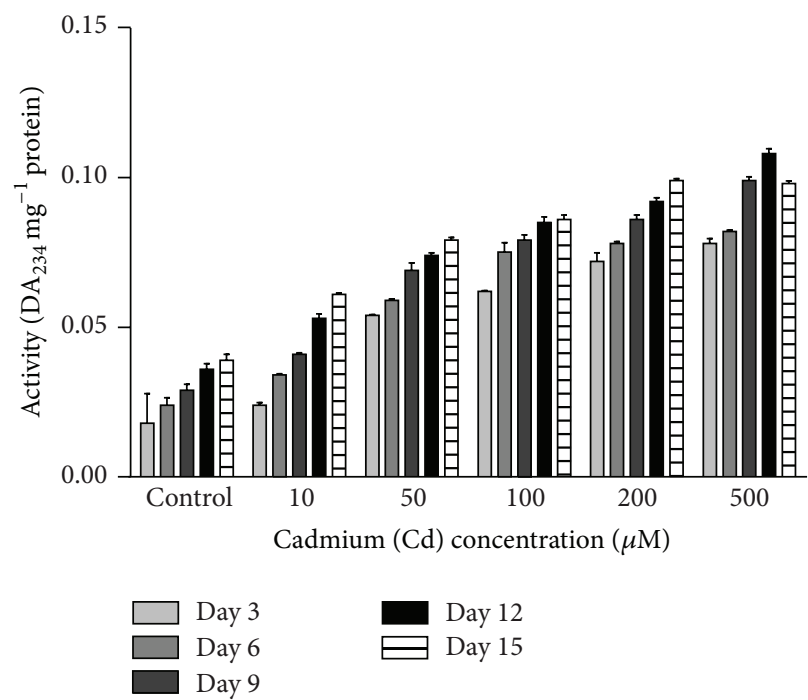

(b)

FIgURE 8: Changes in tissue lipoxygenase activity. (a) Leaf and (b) root. Data shown in each bar are mean \pm SE of 3 trials of each experiment with at least 10 plants, analyzed by Dunnett's test (at $5 \%$ level of significance).

3.9. Changes in Nonenzymatic Antioxidants. Ascorbic acid (AsA) content was found to be slightly decreased in leaves of cadmium stressed plants compared to respective controls. However, a significant increase in ascorbate content was observed in roots, with higher levels recorded in $500 \mu \mathrm{M}$ cadmium stressed plants on day 15 (Figures 9(a) and 9(c)). Glutathione (reduced) content was found to be significantly increased in leaves and roots of cadmium stressed plants, compared to respective controls, with higher levels recorded in leaves than in roots at all the concentrations of cadmium and duration (Figures 9(b) and 9(d)). Nonprotein thiols (NPSH) and cysteine content were found to be increased in leaves and roots of cadmium stressed plants, compared to respective controls at all the concentrations of cadmium and duration (Figures 10(a), 10(b), 10(c), and 10(d)).

\section{Discussion}

Cadmium is one of the nonessential heavy metal pollutants, which is highly toxic to plants, because of its relatively high mobility in the soil-plant system $[37,38]$. Cadmium stress impairs the physiological and biochemical processes in plants such as photosynthesis, water relations, and mineral uptake $[39,40]$ and also causes disruption of membrane composition and function [41, 42]. Results of the present study in cadmium stressed seedlings of $V$. aconitifolia revealed that cadmium stress affected shoot and root growth (Figure 1) and tissue dry matter accumulation (Figure 2). The results of cadmium quantitative analysis revealed that cadmium has accumulated in both leaves and roots on a concentration dependent manner supplemented in the medium (Figure 3), suggesting the possible translocation of cadmium from roots to aerial parts (leaves) at all the concentrations used to impose stress. Cadmium reaches the aerial parts through the xylem by easily penetrating root system of xylem $[43,44]$. Cadmium quantification (Figure 3) in moth bean plants clearly suggests that leaves are also affected by cadmium stress, which might be due to the translocation of this trace metal from roots to aerial parts like shoots and leaves in moth bean plant. Cadmium affects moth bean growth and leaf pigment composition $[24,25]$. The difference in cadmium uptake and tissue distribution may act as the first defense line by reducing the toxic metal level in organs or cells [45].

Leaf relative water content (RWC) and cell membrane stability were affected in the stressed seedlings compared to nonstressed control seedlings (Figures 4 and 5). Higher loss in RWC was observed in leaves (67\%) compared to roots (56\%); further this loss of RWC was observed to be dependent on severity of stress and duration of exposure of seedlings to the stress Figures 4(a) and 4(b). Similar findings were also reported in lettuce [46] and radish seedlings [47] that cadmium exposure reduced the relative water contents. Reference [48] demonstrated that cadmium decreases leaf conductance and interacts with stomatal regulation in a concentration dependent manner which is a manifestation of cadmium toxicity in plants that is not influenced by abscisic acid. Plant water status reflects the metabolic activity that is measured as RWC in leaves [49]. The altered leaf RWC and cell membrane damage (\% injury) confirms the manifestation of cadmium toxicity in stressed $V$. aconitifolia seedlings, which might be due to the elevated levels of ROS in both superoxide radicals and hydrogen peroxide (Figure 6). Published data from other plant species suggests that cadmium alters the cellular redox state, by increasing the production of reactive oxygen species (ROS) like $\mathrm{H}_{2} \mathrm{O}_{2}$ (hydrogen peroxide), $\mathrm{O}_{2}{ }^{-}$(superoxide), and $\mathrm{OH}^{*}$ (hydroxyl radicals) [37, 50]. Accumulation of ROS such as $\mathrm{H}_{2} \mathrm{O}_{2}$ and $\mathrm{O}_{2}{ }^{--}$in cell invariably damages the components such as DNA, protein, and lipids. Growing evidence suggests that a correlation exists between the rate of increase in $\mathrm{H}_{2} \mathrm{O}_{2}$ 

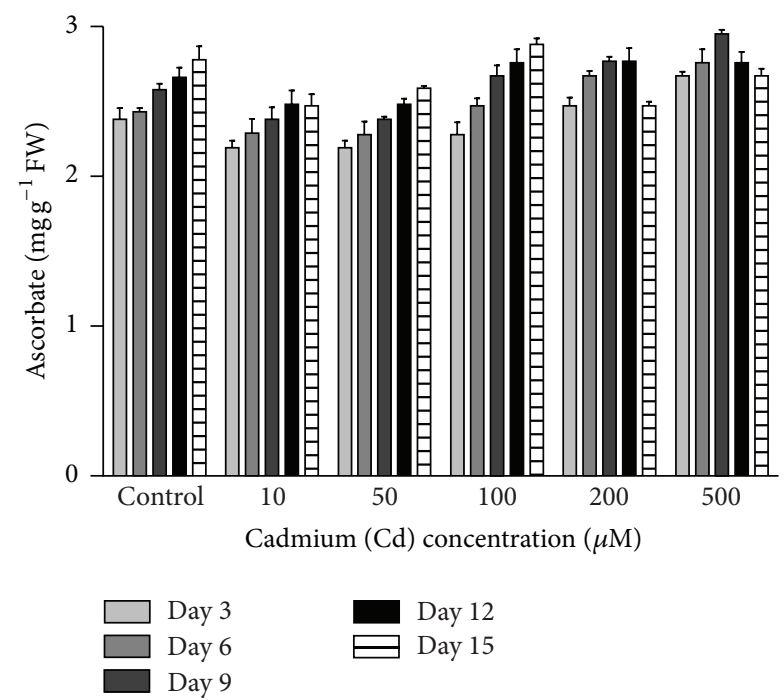

(a)
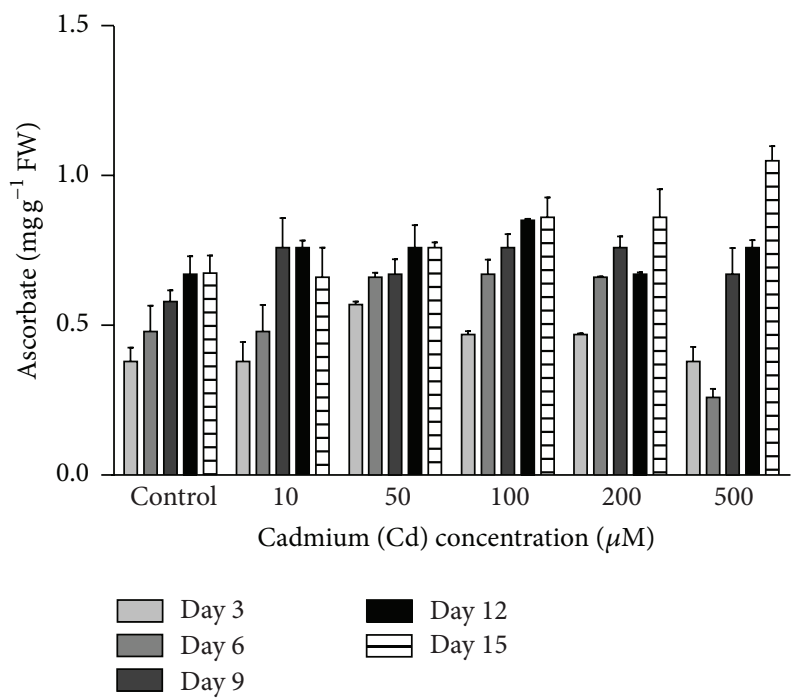

(c)
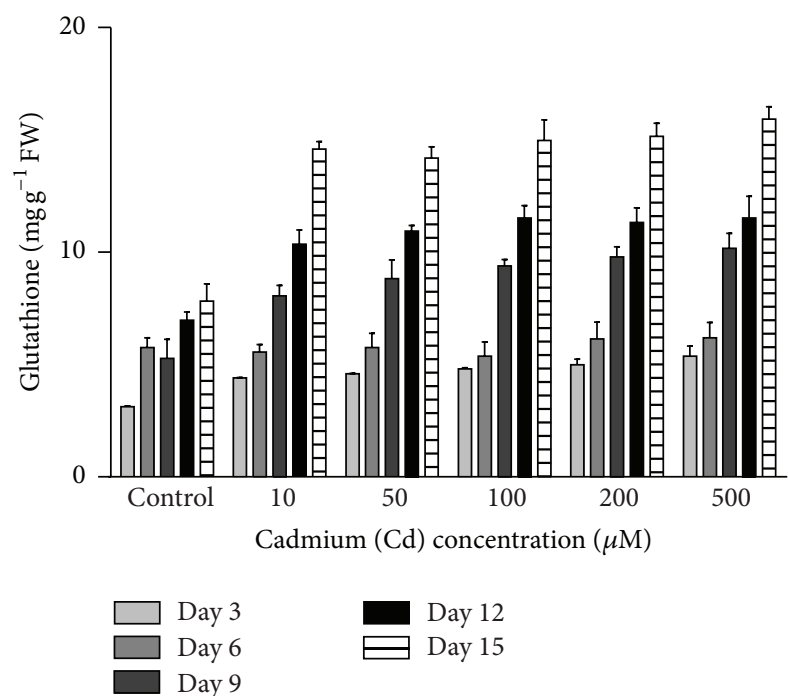

(b)
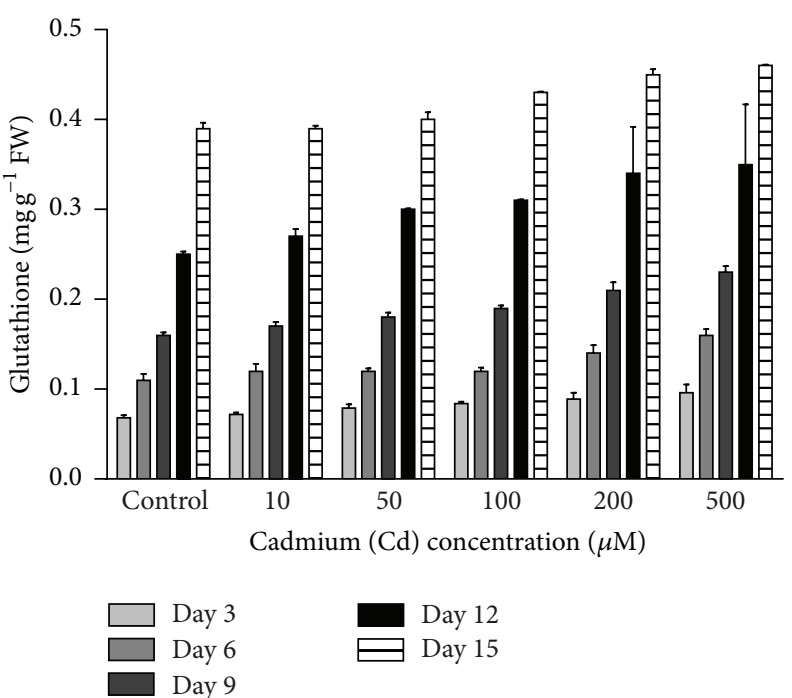

Day 15

(d)

FIGURE 9: Changes in ascorbate (AsA) and reduced glutathione (GSH) levels. (a) Leaf AsA, (b) leaf GSH, (c) root AsA, and (d) root GSH. Data shown in each bar are mean \pm SE of 3 trials of each experiment with at least 10 plants, analyzed by Dunnett's test (at $5 \%$ level of significance).

content and level of membrane lipid peroxidation as well as electrolyte leakage that are often used as biochemical markers to assess the extent of oxidative damage in plants under stress [51-53].

To this perspective, results of the present study strongly indicate the onset of cadmium-induced oxidative stress manifested as oxidative damage to membranes in the $V$. aconitifolia seedlings, as observed by the increase in amounts of TBARS (malondialdehyde), carbonyl content in leaves and roots, which are the products of membrane lipid peroxidation and protein oxidation, respectively (Figures $7(\mathrm{a}), 7(\mathrm{~b}), 7(\mathrm{c})$, and $7(\mathrm{~d})$ ). Increase in TBARS content is assumed to be a common symptom of heavy metal stress [54-56]. Protein oxidation in stressed tissues is the most commonly occurring oxidative modification; accumulation of oxidized proteins reflects not only the rate of protein oxidation but also the rate of oxidized protein degradation $[32,57]$. Increase in TBARS content could be correlated with the elevated levels of lipoxygenase activity (Figure 8). Lipoxygenases are a family of enzymes that catalyze oxygenation of polyunsaturated fatty acids (PUFAs) into lipid hydroperoxides (LOOHs) involved in stress responses [58]. Elevation in lipoxygenase activity during altered cellular redox state was reported in other plants also $[58,59]$.

Nonenzymatic mechanisms of ROS detoxification can also operate during plant stress, and the main nonenzymatic antioxidants include ascorbate and glutathione (GSH), nonprotein thiols in metal stress [60-62]. After application of heavy metals, the ascorbate-glutathione cycle seems to be a mechanism of great importance in controlling the cellular redox status [63]. It was observed during the present study that the amount of ascorbic acid (Figures 9(a) and 9(c)) 

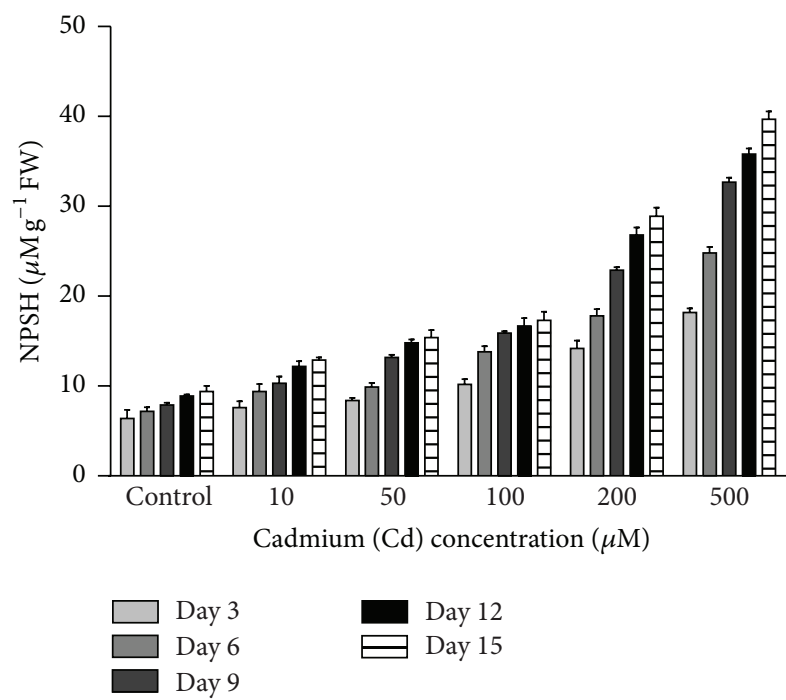

(a)
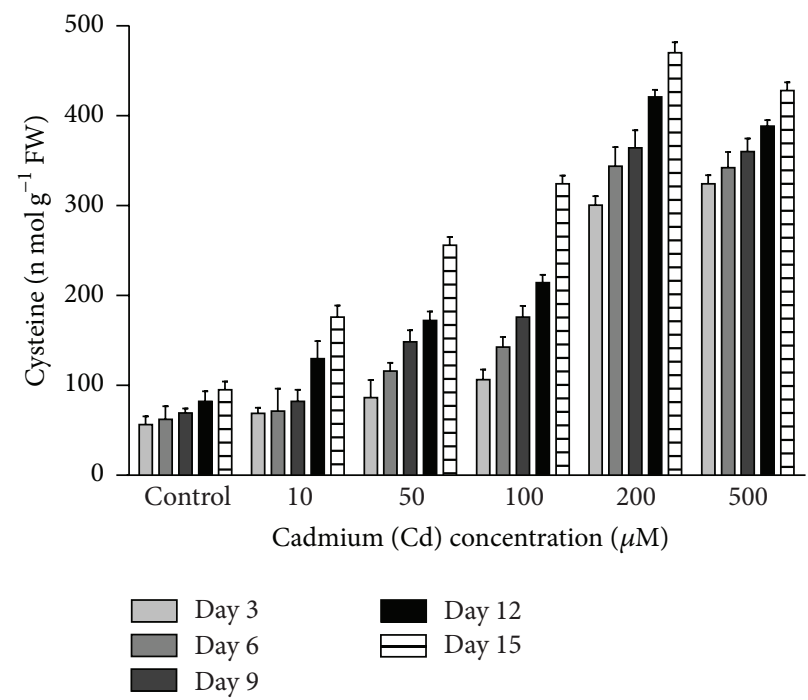

E Day 15

(c)

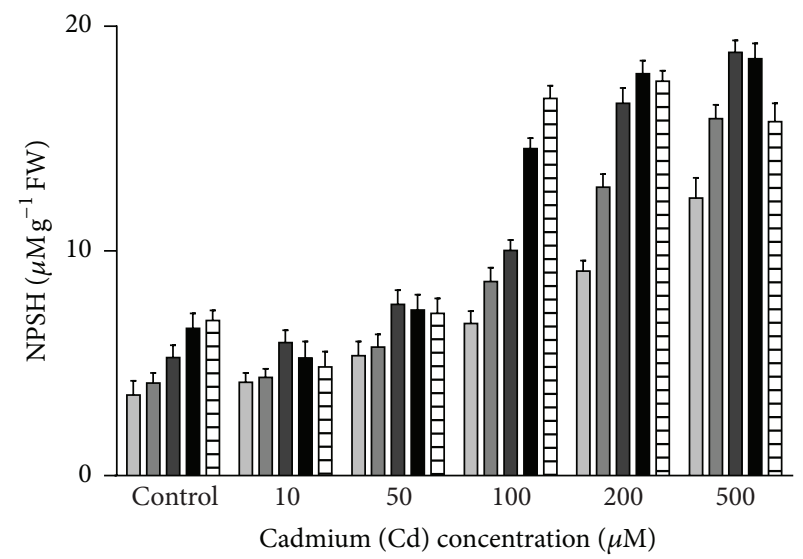

$\square$ Day 3
$\square$ Day 6
$\square$ Day 9

Day 12

Day 15

(b)

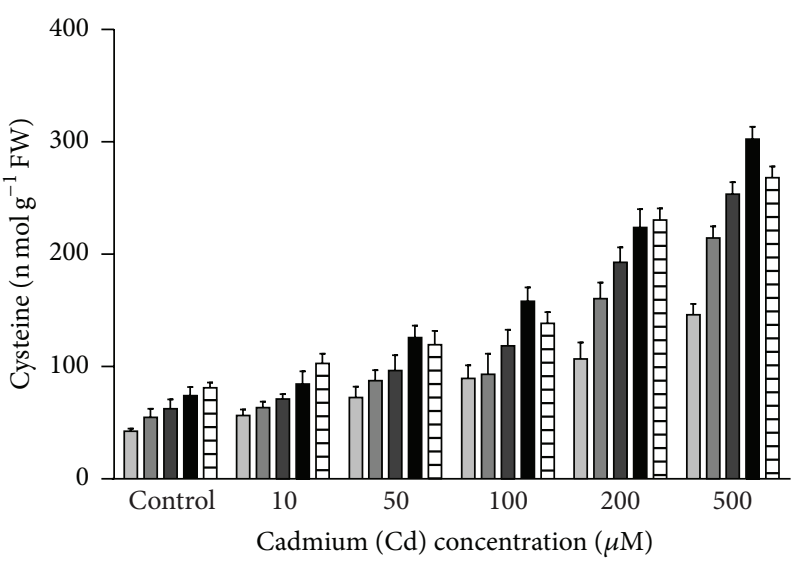

$\square$ Day 3
$\square$ Day 6
$\square$ Day 9

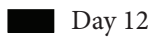

Day 15

(d)

FIGURE 10: Changes in tissue nonprotein thiols (NPSH) and cysteine (Cys) content. (a) Leaf NPSH, (b) root NPSH, (c) leaf Cys, and (d) root Cys. Data shown in each bar are mean \pm SE of 3 trials of each experiment with at least 10 plants, analyzed by Dunnett's test (at $5 \%$ level of significance).

remained more or less stable during the entire period of study, while glutathione (GSH) (Figures 9(b) and 9(d)), other nonprotein thiols, and cysteine concentration (Figures 10(a), 10(b), 10(c), and 10(d)) were increased in cadmium stressed $V$. aconitifolia seedlings with increase in Cd stress intensity. Ascorbate is a primary as well as a secondary antioxidant [58, $62,63]$ that may bind metals, thereby affecting their movement across biological membranes, or may act as a reducing agent, protecting the oxidation of the mercapto $(-\mathrm{SH})$ groups by contributing electron or reducing power for photosystem II [64]. Similarly GSH is a well characterized antioxidant that plays a prominent role in defense system of plants [4] and plays a central role in the regeneration of ascorbate and functions as an antioxidant scavenging radical, and also GSH is the direct substrate for the synthesis of phytochelatins (PC), which chelate the metals. The nonprotein thiols (NPSH) and cysteine were measured during the present study because of their importance in polythiol synthesis (phytochelatin) and metal sequestration $[65,66]$.

$\mathrm{H}_{2} \mathrm{O}_{2}$ appears to be a central signal component of plant adaptation to both biotic and abiotic stresses [40]. Previous studies in other plants have given several lines of evidence indicating that cadmium exposure increased the production of $\mathrm{H}_{2} \mathrm{O}_{2}[57,67,68]$. The consistent increase of $\mathrm{H}_{2} \mathrm{O}_{2}$ (Figures 6(a) and 6(b)) and ascorbate contents in leaves and roots (Figures 9(a) and 9(c)) and also elevated levels of reduced glutathione (Figures 9(b) and 9(d)) and nonprotein thiols in the leaves and roots (Figures 10(a), 10(b), 10(c), and 10(d)) of $V$. aconitifolia seedlings with increasing intensity of cadmium stress in the present study suggest that $\mathrm{H}_{2} \mathrm{O}_{2}$ might have 
induced signal transduction cascade seedlings to the imposed cadmium stress. With the increased nonenzymatic antioxidants nonprotein thiols, and translocation of cadmium from roots to leaves, these mechanisms probably confer the cadmium stress tolerance of $V$. aconitifolia seedlings.

\section{Conclusions}

Cadmium is one of heavy metals that accumulates in the agriculture soil at toxic levels due to anthropogenic activity. In the present study it has been observed that cadmium affected the physiological and biochemical parameters in both leaves and roots by altering redox status, increased lipoxygenase activity, and affected RWC and cell membrane stability in moth bean ( $V$. aconitifolia) seedlings. In spite of these effects of cadmium, moth bean could maintain its growth vigour by minimizing the cadmium toxicity not only by translocation of cadmium from rhizosphere to aerial parts, but also by inducing the $\mathrm{H}_{2} \mathrm{O}_{2}$ mediated signaling, maintaining the active operation of ascorbate-glutathione cycle and increasing the concentration of nonprotein thiols and cysteine content. In the present study, it has been demonstrated that, unlike other cadmiumsensitive legumes, moth bean is tolerant to cadmium toxicity at the levels studied. Further studies are to be carried out at cellular and molecular level to confirm the possible cadmium withstanding potential of $V$. aconitifolia.

\section{Competing Interests}

The authors declare that there are no competing interests regarding the publication of this paper.

\section{References}

[1] Y. J. Cui, Y.-G. Zhu, R. H. Zhai, Y. Huang, Y. Qiu, and J. Z. Liang, "Exposure to metal mixtures and human health impacts in a contaminated area in Nanning, China," Environment International, vol. 31, no. 6, pp. 784-790, 2005.

[2] L. Sanità Di Toppi and R. Gabbrielli, "Response to cadmium in higher plants," Environmental and Experimental Botany, vol. 41, no. 2, pp. 105-130, 1999.

[3] F. Rivera-Becerril, C. Calantzis, K. Turnau et al., "Cadmium accumulation and buffering of cadmium-induced stress by arbuscular mycorrhiza in three Pisum sativum L. genotypes," Journal of Experimental Botany, vol. 53, no. 371, pp. 1177-1185, 2002.

[4] S. Clemens, "Toxic metal accumulation, responses to exposure and mechanisms of tolerance in plants," Biochimie, vol. 88, no. 11, pp. 1707-1719, 2006.

[5] L. Zhao, Y.-L. Sun, S.-X. Cui et al., "Cd-induced changes in leaf proteome of the hyperaccumulator plant Phytolacca americana," Chemosphere, vol. 85, no. 1, pp. 56-66, 2011.

[6] R. Anita, L. K. Chugh, V. Sawhney, and S. K. Sawhney, "Effect of cadmium and chromium on seed germination and growth of peas," in Proceedings of Environmental Pollution, S. K. Arora, M. Singh, and R. P. Aggarwal, Eds., pp. 66-77, Haryana Agricultural University Press, Hisar, India, 1990.

[7] N. C. Aery and D. K. Rana, "Growth and cadmium uptake in barley under cadmium stress," Journal of Environmental Biology, vol. 24, no. 2, pp. 117-123, 2003.
[8] F. Van Assche and H. Clijsters, "Effects of metals on enzyme activity in plants," Plant, Cell \& Environment, vol. 13, no. 3, pp. 195-206, 1990.

[9] M. N. V. Prasad, "Cadmium toxicity and tolerance in vascular plants," Environmental and Experimental Botany, vol. 35, no. 4, pp. 525-545, 1995.

[10] F. Pinot, S. E. Kreps, M. Bachelet, P. Hainaut, M. Bakonyi, and B. S. Polla, "Cadmium in the environment: sources, mechanisms of biotoxicity, and biomarkers," Reviews on Environmental Health, vol. 15, no. 3, pp. 299-323, 2000.

[11] K. Peng, X. Li, C. Luo, and Z. Shen, "Vegetation composition and heavy metal uptake by wild plants at three contaminated sites in Xiangxi area, China," Journal of Environmental Science and Health-Part A Toxic/Hazardous Substances and Environmental Engineering, vol. 41, no. 1, pp. 65-76, 2006.

[12] S. S. Kadam and D. K. Salunkhe, "Nutritional composition, processing, and utilization of horse gram and moth bean," Critical Reviews in Food Science and Nutrition, vol. 22, no. 1, pp. 1-26, 1985.

[13] R. Adsule, "Moth bean (Vigna aconitifolia (Jacq.) Marechal)," in Food and Feed from Legumes and Oil Seeds, E. Nwokolo and J. Smart, Eds., pp. 203-205, Chapman \& Hall, London, UK, 1996.

[14] L. Bravo, P. Siddhuraju, and F. Saura-Calixto, "Effect of various processing methods on the in vitro starch digestibility and resistant starch content of indian pulses," Journal of Agricultural and Food Chemistry, vol. 46, no. 11, pp. 4667-4674, 1998.

[15] M. Inouhe, S. Ninomiya, H. Tohoyama, M. Joho, and T. Murayama, "Different characteristics of roots in the cadmiumtolerance and Cd-binding complex formation between monoand dicotyledonous plants," Journal of Plant Research, vol. 107, no. 3, pp. 201-207, 1994.

[16] Y.-M. Li, R. L. Chaney, A. A. Schneiter, J. F. Miller, E. M. Elias, and J. J. Hammond, "Screening for low grain cadmium phenotypes in sunflower, durum wheat and flax," Euphytica, vol. 94, no. 1, pp. 23-30, 1997.

[17] D. Ci, D. Jiang, T. Dai, Q. Jing, and W. Cao, "Variation in cadmium tolerance and accumulation and their relationship in wheat recombinant inbred lines at seedling stage," Biological Trace Element Research, vol. 142, no. 3, pp. 807-818, 2011.

[18] G. Saeidi, M. Rickauer, and L. Gentzbittel, "Tolerance for cadmium pollution in a core-collection of the model legume, Medicago truncatula L. at seedling stage," Australian Journal of Crop Science, vol. 6, no. 4, pp. 641-648, 2012.

[19] R. P. S. Kharb, V. P. Singh, and Y. S. Tomar, "Moth bean (Vigna aconitifolia Jacq. (Mareehal)). A review," Forage Research Journal, vol. 13, pp. 113-132, 1987.

[20] A. M. A. Mazen, "Assessment of heavy metal accumulation and performance of some physiological parameters in Zea mays L. and Vicia faba L. grown on soil amended by sewage sludge resulting from sewage water treatment in the state of Qatar," Qatar University Science Journal, vol. 15, pp. 353-359, 1995.

[21] D. A. Cataldo, T. R. Garland, and R. E. Wildung, "Cadmium uptake kinetics in intact soybean plants," Plant Physiology, vol. 73 , no. 3, pp. 844-848, 1983 .

[22] R. H. Dowdy and G. E. Ham, "Soybean growth and elemental content as influenced by soil amendments of sewage sludge and heavy metals: seedling studies," Agronomy Journal, vol. 69, no. 2, pp. 300-303, 1977.

[23] S. A. Hasan, B. Ali, S. Hayat, and A. Ahmad, "Cadmiuminduced changes in the growth and carbonic anhydrase activity of chickpea," Turkish Journal of Biology, vol. 31, no. 3, pp. 137140, 2007. 
[24] K. K. Bora, S. R. Mathur, and M. Lal, "Relative physiological and biochemical tolerance in moth bean cultivars to cadmium stress," Current Agriculture, vol. 27, pp. 81-84, 2003.

[25] S. R. Mathur, K. B. Shukla, and M. K. Sharma, "Effect of cadmium on seedling growth, lipid peroxidation and photosynthetic pigments of mothbean cultivar," International Journal of Plant Sciences, vol. 1, no. 2, pp. 200-201, 2006.

[26] D. R. Hoagland and D. I. Arnon, The Water Culture Method for Growing Plants without Soil, Circular 347, California Agricultural Experimental Station, University of California, Berkeley, Berkeley, Calif, USA, 1950.

[27] Z. Wang, Y. Zhang, Z. Huang, and L. Huang, "Antioxidative response of metal-accumulator and non-accumulator plants under cadmium stress," Plant and Soil, vol. 310, no. 1-2, pp. 137149, 2008.

[28] S. Choudhury and S. K. Panda, "Toxic effects, oxidative stress and ultrastructural changes in moss Taxithelium nepalense (Schwaegr.) broth. under chromium and lead phytotoxicity," Water, Air, and Soil Pollution, vol. 167, no. 1-4, pp. 73-90, 2005.

[29] S. Sugisaka, "The occurrence of peroxide in a perennial plant," Populs Gelrica, vol. 57, pp. 308-309, 1976.

[30] P. E. Skorzynska, M. Drazkiewicz, and Z. Krupa, “The activity of the antioxidative system in cadmium-treated Arabidopsis thaliana," Biologia Plantarum, vol. 47, no. 1, pp. 71-78, 2004.

[31] R. L. Heath and L. Packer, "Photoperoxidation in isolated chloroplasts. I. Kinetics and stoichiometry of fatty acid peroxidation," Archives of Biochemistry and Biophysics, vol. 125, no. 1, pp. 189-198, 1968.

[32] L. B. Pena, L. A. Pasquini, M. L. Tomaro, and S. M. Gallego, "Proteolytic system in sunflower (Helianthus annuus L.) leaves under cadmium stress," Plant Science, vol. 171, no. 4, pp. 531-537, 2006.

[33] M. Y. Law, S. A. Charles, and B. Halliwell, "Glutathione and ascorbic acid in spinach (Spinacia oleracea) chloroplasts. The effect of hydrogen peroxide and of Paraquat," Biochemical Journal, vol. 210, no. 3, pp. 899-903, 1983.

[34] O. W. Griffith, "Determination of glutathione and glutathione disulfide using glutathione reductase and 2-vinylpyridine," Analytical Biochemistry, vol. 106, no. 1, pp. 207-212, 1980.

[35] S. S. Sharma, S. Kaul, A. Metwally, K. C. Goyal, I. Finkemeier, and K.-J. Dietz, "Cadmium toxicity to barley (Hordeum vulgare) as affected by varying Fe nutritional status," Plant Science, vol. 166, no. 5, pp. 1287-1295, 2004.

[36] M. K. Gaitonde, "A spectrophotometric method for the direct determination of cysteine in the presence of other naturally occurring amino acids," Biochemical Journal, vol. 104, no. 2, pp. 627-633, 1967.

[37] M. P. Benavides, S. M. Gallego, and M. L. Tomaro, "Cadmium toxicity in plants," Brazilian Journal of Plant Physiology, vol. 17, no. 1, pp. 21-34, 2005.

[38] M. D. Groppa, M. P. Ianuzzo, E. P. Rosales, S. C. Vázquez, and M. P. Benavides, "Cadmium modulates NADPH oxidase activity and expression in sunflower leaves," Biologia Plantarum, vol. 56, no. 1, pp. 167-171, 2012.

[39] U. J. López-Chuken and S. D. Young, "Modelling sulphateenhanced cadmium uptake by Zea mays from nutrient solution under conditions of constant free $\mathrm{Cd}^{2+}$ ion activity," Journal of Environmental Sciences, vol. 22, no. 7, pp. 1080-1085, 2010.

[40] S. S. Gill, N. A. Khan, and N. Tuteja, "Cadmium at high dose perturbs growth, photosynthesis and nitrogen metabolism while at low dose it up regulates sulfur assimilation and antioxidant machinery in garden cress (Lepidium sativum L.)," Plant Science, vol. 182, no. 1, pp. 112-120, 2012.

[41] P. L. Gratão, C. C. Monteiro, M. L. Rossi et al., "Differential ultrastructural changes in tomato hormonal mutants exposed to cadmium," Environmental and Experimental Botany, vol. 67, no. 2, pp. 387-394, 2009.

[42] S. M. Gallego, L. B. Pena, R. A. Barcia et al., "Unravelling cadmium toxicity and tolerance in plants: insight into regulatory mechanisms," Environmental and Experimental Botany, vol. 83, pp. 33-46, 2012.

[43] D. E. Salt and W. E. Rauser, "MgATP-dependent transport of phytochelatins across the tonoplast of oat roots," Plant Physiology, vol. 107, no. 4, pp. 1293-1301, 1995.

[44] M. G. Yang, X. Y. Lin, and X. E. Yang, "Impact of Cd on growth and nutrient accumulation of different plant species," Chinese Journal of Applied Ecology, vol. 9, no. 1, pp. 89-94, 1998.

[45] F.-B. Wu, J. Dong, Q. Q. Qiong, and G.-P. Zhang, "Subcellular distribution and chemical form of Cd and Cd-Zn interaction in different barley genotypes," Chemosphere, vol. 60, no. 10, pp. 1437-1446, 2005.

[46] G. Costa, J. Michaut, and J. Morel, "Influence of cadmium on water relations and gas exchanges, in phosphorus deficient Lupinus albus L.", Plant Physiology and Biochemistry, vol. 32, no. 1, pp. 105-114, 1994.

[47] G. Costa and J. L. Morel, "Water relations, gas exchange and amino acid content in Cd-treated lettuce," Plant Physiology and Biochemistry, vol. 32, no. 4, pp. 561-570, 1994.

[48] L. Perfus-Barbeoch, N. Leonhardt, A. Vavasseur, and C. Forestier, "Heavy metal toxicity: cadmium permeates through calcium channels and disturbs the plant water status," The Plant Journal, vol. 32, no. 4, pp. 539-548, 2002.

[49] D. J. Flower and M. M. Ludlow, "Contribution of osmotic adjustment to the dehydration tolerance of water-stressed pigeon pea (Cajanus cajan (L.) millsp.) leaves," Plant, Cell and Environment, vol. 9, no. 1, pp. 33-40, 1986.

[50] M. C. Romero-Puertas, M. Rodríguez-serrano, F. J. Corpas, M. Gómez, L. A. del Río, and L. M. Sandalio, "Cadmium-induced subcellular accumulation of $\mathrm{O}_{2}^{--}$and $\mathrm{H}_{2} \mathrm{O}_{2}$ in pea leaves," Plant, Cell \& Environment, vol. 27, no. 9, pp. 1122-1134, 2004.

[51] E. Bandeoğlu, F. Eyidoğan, M. Yücel, and H. A. Öktem, "Antioxidant responses of shoots and roots of lentil to $\mathrm{NaCl}$ salinity stress," Plant Growth Regulation, vol. 42, no. 1, pp. 69-77, 2004.

[52] E. López, C. Arce, M. J. Oset-Gasque, S. Cañadas, and M. P. González, "Cadmium induces reactive oxygen species generation and lipid peroxidation in cortical neurons in culture," Free Radical Biology and Medicine, vol. 40, no. 6, pp. 940-951, 2006.

[53] S. K. Tian, L. L. Lu, X. E. Yang, H. G. Huang, K. Wang, and P. H. Brown, "Root adaptations to cadmium-induced oxidative stress contribute to Cd tolerance in the hyperaccumulator Sedum alfredii," Biologia Plantarum, vol. 56, no. 2, pp. 344-350, 2012.

[54] N. Mallick, "Copper-induced oxidative stress in the chlorophycean microalga Chlorella vulgaris: response of the antioxidant system," Journal of Plant Physiology, vol. 161, no. 5, pp. 591597, 2004.

[55] A. M. Reddy, S. G. Kumar, G. Jyothsnakumari, S. Thimmanaik, and C. Sudhakar, "Lead induced changes in antioxidant metabolism of horsegram (Macrotyloma uniflorum (Lam.) Verdc.) and bengalgram (Cicer arietinum L.)," Chemosphere, vol. 60, no. 1, pp. 97-104, 2005. 
[56] S. Singh, S. Eapen, and S. F. D’Souza, “Cadmium accumulation and its influence on lipid peroxidation and antioxidative system in an aquatic plant, Bacopa monnieri L.," Chemosphere, vol. 62, no. 2, pp. 233-246, 2006.

[57] L. Garnier, F. Simon-Plas, P. Thuleau et al., "Cadmium affects tobacco cells by a series of three waves of reactive oxygen species that contribute to cytotoxicity," Plant, Cell and Environment, vol. 29, no. 10, pp. 1956-1969, 2006.

[58] G. Spiteller, "The relationship between changes in the cell wall, lipid peroxidation, proliferation, senescence and cell death," Physiologia Plantarum, vol. 119, no. 1, pp. 5-18, 2003.

[59] E. Skórzyńska-Polit, B. Pawlikowska-Pawlęga, E. Szczuka, M. Drążkiewicz, and Z. Krupa, "The activity and localization of lipoxygenases in Arabidopsis thaliana under cadmium and copper stresses," Plant Growth Regulation, vol. 48, no. 1, pp. 2939, 2006.

[60] C. H. Foyer, "Ascorbic acid," in Antioxidants in Higher Plants, R. G. Alscher and J. L. Hess, Eds., pp. 31-58, CRC Press, Boca Raton, Fla, USA, 1993.

[61] C. H. Foyer and G. Noctor, "Redox regulation in photosynthetic organisms: signaling, acclimation, and practical implications," Antioxidants and Redox Signaling, vol. 11, no. 4, pp. 861-905, 2009.

[62] P. Ahmad, C. A. Jaleel, M. A. Salem, G. Nabi, and S. Sharma, "Roles of enzymatic and nonenzymatic antioxidants in plants during abiotic stress," Critical Reviews in Biotechnology, vol. 30, no. 3, pp. 161-175, 2010.

[63] A. Cuypers, J. Vangronsveld, and H. Clijsters, "Peroxidases in roots and primary leaves of Phaseolus vulgaris Copper and Zinc Phytotoxicity: a comparison," Journal of Plant Physiology, vol. 159, no. 8, pp. 869-876, 2002.

[64] K. P. Gowrinatha and V. N. R. Rao, "Reversal of heavy metal toxicity by ascorbic acid in microalgae," Journal of Swap-Bot, vol. 9, pp. 27-29, 1992.

[65] D. D. Perrin and A. E. Watt, "Complex formation of zinc and cadmium with glutathione," Biochem Biophys Acta (BBA)General Subjects, vol. 230, no. 1, pp. 96-104, 1971.

[66] M. Oven, J. E. Page, M. H. Zenk, and T. M. Kutchan, "Molecular characterization of the homo-phytochelatin synthase of soybean Glycine max: relation to phytochelatin synthase," The Journal of Biological Chemistry, vol. 277, no. 7, pp. 4747-4754, 2002.

[67] Y. T. Hsu and C. H. Kao, "Toxicity in leaves of rice exposed to cadmium is due to hydrogen peroxide accumulation," Plant and Soil, vol. 298, no. 1-2, pp. 231-241, 2007.

[68] K. Verma, G. S. Shekhawat, A. Sharma, S. K. Mehta, and V. Sharma, "Cadmium induced oxidative stress and changes in soluble and ionically bound cell wall peroxidase activities in roots of seedling and 3-4 leaf stage plants of Brassica juncea (L.) czern," Plant Cell Reports, vol. 27, no. 7, pp. 1261-1269, 2008. 

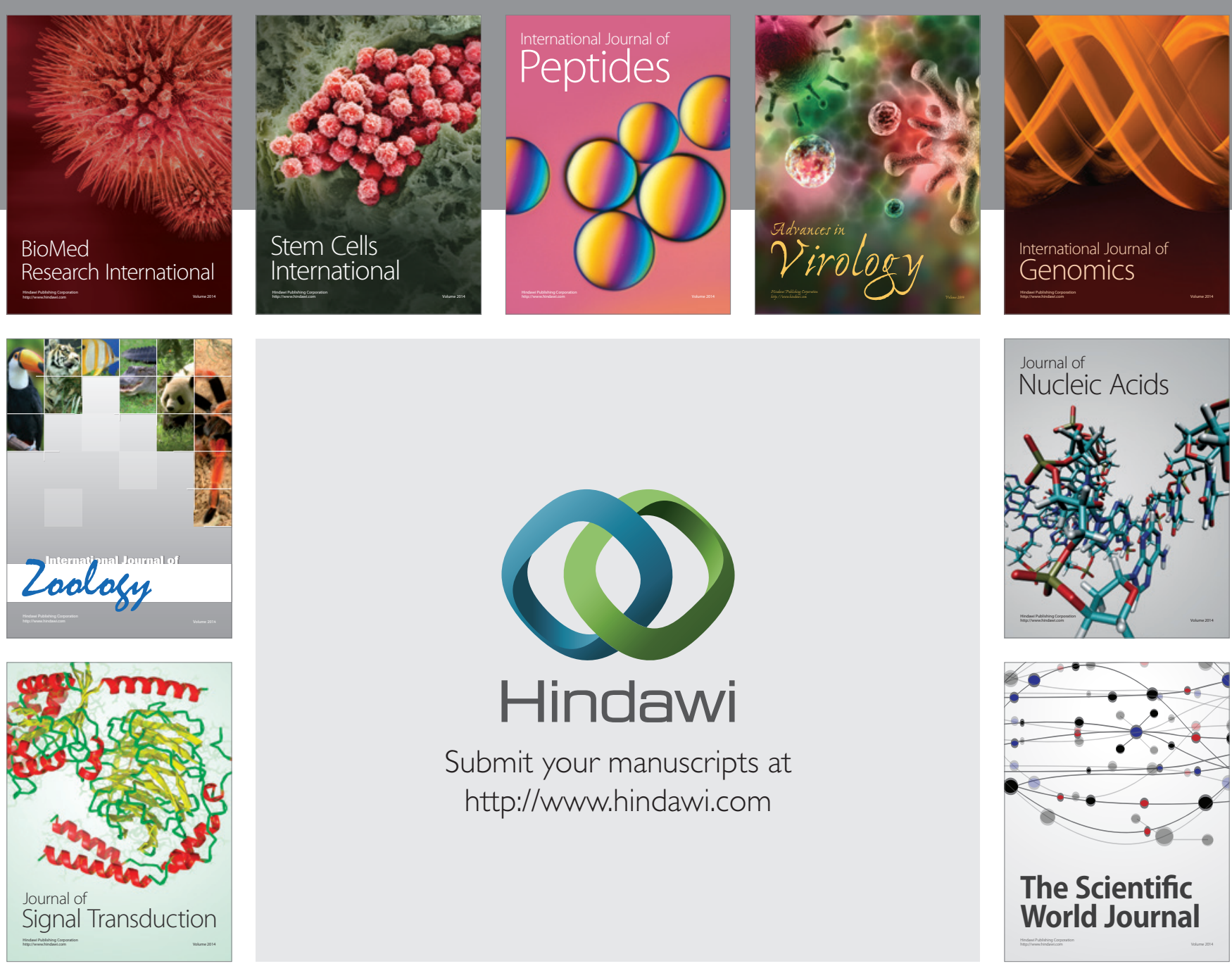

Submit your manuscripts at

http://www.hindawi.com
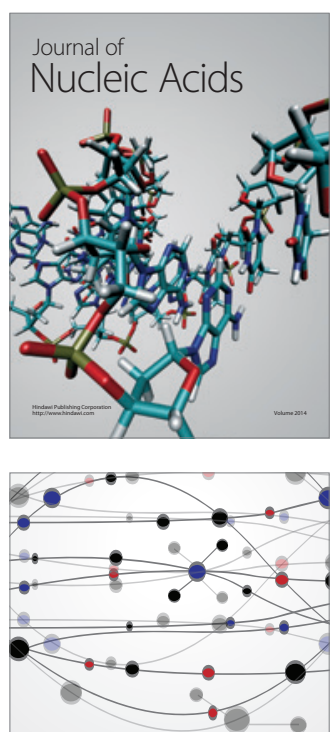

The Scientific World Journal
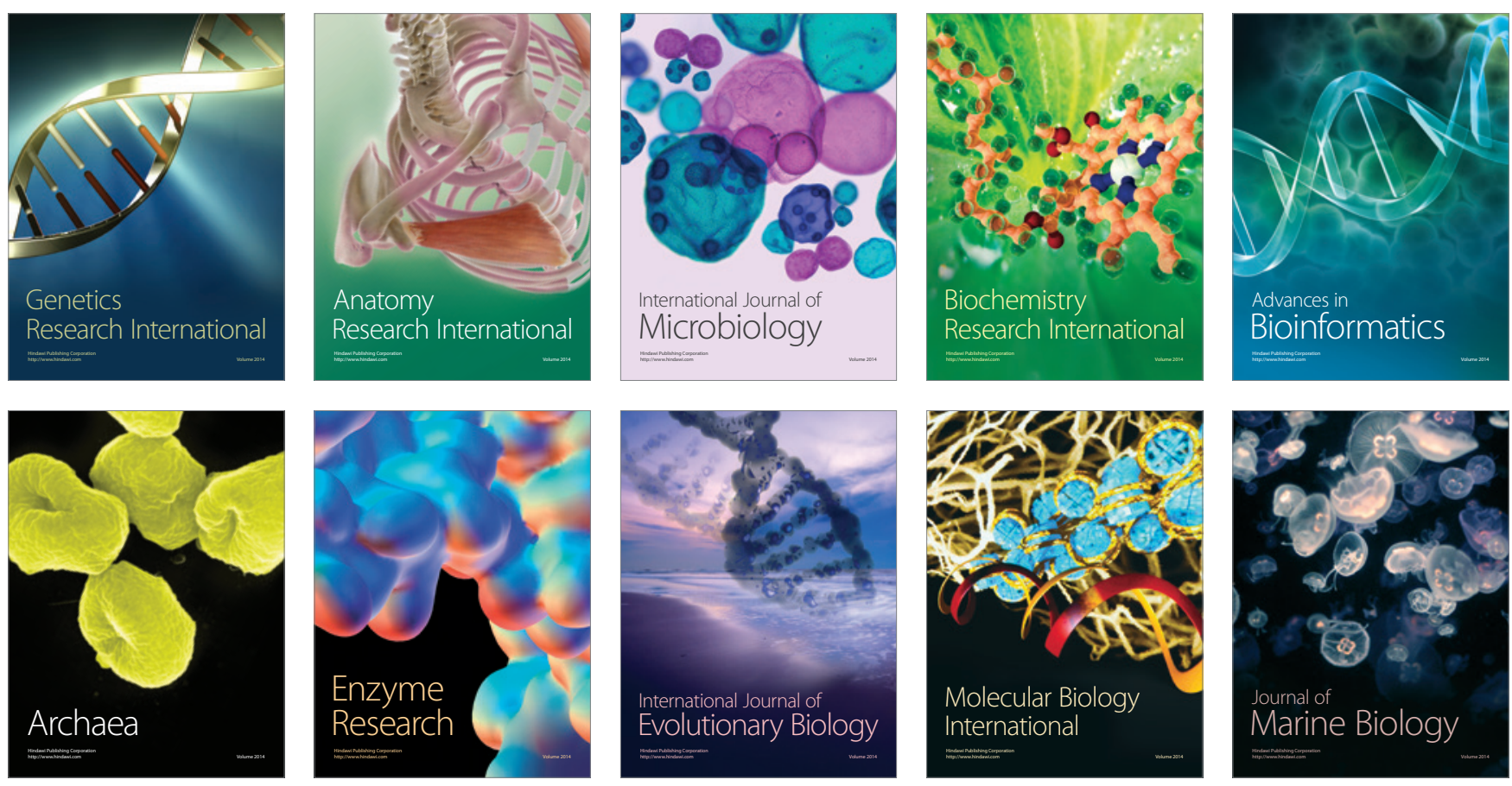